\title{
We are here, \\ we are queer and we are so used to it!
}

\author{
Af Lovise Haj Brade, Erika Lundell \\ og Sebastian MoHr
}

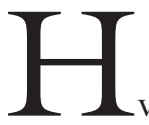

vad er det der 'kvæær'

egentlig? Dette spørgsmål synes altid at klistre til tekster og praksisser med queer som udgangspunkt, og dets svar bliver ofte tøvende, hængende i luften - ambivalent, utydeligt og afhængig af kontekst. For den som stiller spørgsmålet, bliver svaret næsten aldrig så konkret som hen håbede på. $\mathrm{Og}$ for den som forventes at svare, bliver diffuse henvisninger til kombinationer af poststrukturalistiske forståelsesrammer, kritiske heteronormativitesstudier og selvvalgte (anti)identitetspositioner oftest det mest nærliggende, men sjældent helt dækkende, svar. Dette gxlder ikke kun i Danmark, men måske er uklarhederne særligt udbredte her og i andre ikke-engelsktalende lande, hvor queer som begreb ikke har en historie i sig selv. Hvor ordet i USA og Storbritannien semantisk og affektivt er knyttet til menneskers erfaringer med at blive uddefineret, truet og til og med myrdet for deres association med et kollektiv, der opfattes som afvigende fra de seksuelle og kønslige logik- 
ker, som opretholder heteronormativiteten, fremstår queerbegrebet i Danmark og Skandinavien som en primært akademiskteoretisk analyseprisme og/eller et (identitets)projekt tilknyttet det venstreorienterede politiske miljø uden reel tilknytning til den historiske kamp mod undertrykkelse af LGBTI-personer ${ }^{1}$ i Danmark - i større grad associeret til den nutidige kamp.

Vi venter stadig på den danske genealogi over queerbegrebet, men overordnet er queer teorier i den danske (akademiske), og mere generelt nordiske, offentlighed blevet modtaget som et i grunden positivt udfordrende, udviklende og delvist uforudsigeligt perspektiv på en ellers velkendt verden. Men som Dag Heede påpeger i sin tilblivelseshistorie som dansk queer forsker og 'rigsfisselette' i jubilæumsnummeret af Kvinder, Køn \& Forskning (nr. 4 2012), var pladsen, der blev beredt for nye ikke-normative kritiske teorier i det akademiske miljø i lang tid meget begrænset, og det var først efter årtusindskiftet, at queer forskning begyndte at rykke i Danmark (Heede 2012). Allerede i 1996 kom dog det nordiske tidskrift lambda nordicas første særnummer om queer teori, og dette efterfulgtes i Sverige af en række bøger og artikler dedikeret specifikt til dette emne (f.eks. Rosenberg 2002; Ambjörnsson 2006; Kulick 2005; Berg and Wickman 2010). Også i Norge har queer været på dagsordenen i længere tid, hvilket blandt andet har medført, at det velkendte tidsskrift Journal of Homosexuality i 2008 havde et særnummer om queer teori i Norge (Bjørby and Ryall 2008). De interskandinaviske genealogier er således forskellige, men fælles er, at queer teori i sin danske og skandinaviske adaption er opstået på radikalt andre præmisser end sin amerikanske forgænger og er som sådan i en vis grad blevet omgxrdet med en popkulturel chique og (i visse versioner) omfavnet af en senmoderne kapitalistisk logik, der hurtigt har opsnappet og forvandlet dets kritiske momentum til en etiket for konsumentkulturens postmoderne ironiske identitetsprojekt. I antologien Queersverige beskriver Don Kulick, hvordan begrebet lige fra starten har været både beriget med og forpestet af en aura af hip-ness (ikke mindst i det akademiske miljø) (Kulick 2005: 17), som løber parallelt med dets radikale politiske ambition om et opgør med det heteroseksuelle etablissement. Med andre ord er queer kendetegnet af en grundlæggende ambivalens mellem kritik og tilpasning, der kan ses som et resultat af en udbredt tendens til at glemme queer teoriers seksualpolitiske rødder og ignorere nødvendigheden af en fortsat ubekvem sexradikal analyse af samfundshegemonier og -problematikker. En af de kontroverser, der var afgørende for udviklingen af queer som aktivisme såvel som akademisk miljø, var de såkaldte 'sex wars' i 1970- og 1980ernes USA, der imploderede spørgsmål om seksualitet, patriarkat, solidaritet og mulige koalitioner (se f.eks. Duggan et al 1995 og Ferguson 1984). (Queer) feminister som Carole Vance, Gayle Rubin og Esther Newton mente, at seksualiteten kunne udforskes som et terræn for individuel omfortolkning af hegemoniske magtforhold (Vance 1976), mens radikalfeminister som Andrea Dworkin, Sheila Jeffreys og Catherine MacKinnon fremførte, at seksualiteten forst og fremmest er (blevet gjort til) et domæne for mænds dominans over og vold mod kvinder (Dworkin 1989). Denne konflikt kom til at påvirke den videre udvikling af såvel radikalfeministisk som queer arbejde betydeligt - og udgør stadig kernen i aktuelle internfeministiske debatter i Danmark om fx prostitution, trans* personers rettigheder og surrogatmoderskab. Seksualitet som praksis, der udfordrer og vælter forgivettagne normer om, hvad der er rigtigt og forkert, godt og dårligt, syndigt og dydigt, er stadig et vanskeligt emne, og som blandt andre Don Kulick har påpeget, er lige præcis denne konflikt særligt betydningsfuld for queer teoriers tilværelse i de nordiske kontekster: den må 
gerne bruges som optik på og (ikke for skarp) kritik mod stabile køn og heteronormativitet generelt. Men når menneskers konkrete seksuelle begær og praksisser og deres funktion i opretholdelsen eller destabiliseringen af heteronormativitetens hegemoni udpeges, og konklusionerne bliver svære eller ubekvemme, så tenderer den radikale queer analyse til at fortage sig i konsensus (Kulick 2005: 18-19). Set i denne optik kan de skandinaviske adaptioner af queer og queer teorier let afskrives som blege, ufarlige og afradikaliserede hygge-versioner af sit radikale og revolutionære ophav, hvilket også redaktørerne af det tidligere temanummer af Kvinder, Køn \& Forskning om queer teorier (Skave køn nr. 1 2003), Dorte Staunæs og Cathrine Egeland, påpegede og advarede mod $\mathrm{i}$ deres indledning. En nylig intervention mod denne lidt ensidige beskrivelse præsenteres i antologien Queer in Europe (Downing \& Gillett 2011), hvori den fem(me)inistiske forsker Ulrika Dahl påpeger, at queer (forskning) i sin skandinaviske adaption i mange henseender har kxmpet med at bygge bro til feminismen, og at dette har resulteret $\mathrm{i}$ en relativt udbredt queerfeminisme (se f.eks. Rosenberg 2002) og en konstant queer udfordring og (gen)opfinden af sig selv og sin egen udvikling. At dette kan kritiseres som problematisk i relation til queeraktivismens sexradikale ophav er, mener Dahl, nok mest et problem for de hvide bøsser, der ikke allierer sig med den feministiske kamp (Dahl 2011). Begrebets betydning og genealogi er således foranderlig afhængigt af position. Hvor nogle kan opfatte brobygningen mellem queer og visse (skandinaviske) feminismer som et tab af en vis form for (sex)radikalitet, kan andre læse queerbegrebets politiske og teoretiske alliancer med radikale bevægelser som feminisme, antiracisme og socialisme som selvfølgelige måder at vinde relevans og legitimitet $i$ et $i$ stigende grad afpolitiseret videnskabsfelt.

\section{QUEER BILLEDER}

Billedfortolkning er altid kontekstafhængig, subjektiv og flertydig. Det visuelle akkompagnement til denne udgave af Kvinder, Køn \& Forskning præsenterer et sådant flertydigt og selvstændigt indlæg i ovennævnte samtale om queers (mangel på) (sex)radikalitet og består af et udvalg af billeder fra fotografen og filmskaberen Bruce LaBruces lange karriere. I sine fotoserier udfordrer LaBruce forgivettagne opfattelser af, hvad der er smukt og hæsligt, tiltrækkende og frastødende, normalt og unormalt. Vi er meget stolte over i dette nummer at kunne bidrage med ikke alene videnskabelige, men også æstetiske bud på, hvordan normbrydende seksualitets- og normudfordrende radikalitetspositioner kan se ud i det queerteoretiske tankeunivers. LaBruce er et centralt navn indenfor queer visuel kunst, og hans virke som aktivist, filminstruktør og fotograf spænder over næsten tre årtier og kendetegnes af en konstant og konsekvent kritik af konformitet og konservatisme. Blandt hans mest kendte værker er filmene Super 81/2 (1993), Rasberry Reich (2004) og L.A. Zombie (2010), der alle stiller ubekvemme spørgsmål om liv, død, seksualitet, konsumentkultur, fascistiske bevægelser og meget mere.

LaBruces værker bryder ikke bare sociale tabuer om, hvad der er acceptabelt at afbilde, men også med en heteronormativ logik, i hvilken den kvindelige krop først og fremmest skal være dydig og reproduktiv, og den mandlige lyst ikke kan indebære underkastelse og andre mænds kropsvæsker. Men samtidigt med disse normbrud kan billederne også læses som en linje af hvide maskuliniteter, og de vækker dermed spørgsmål om, hvorvidt der særligt på den queer kamp mod heteronormativitetens omklamring hviler et ansvar for at blive ved med at spørge til, hvilke slags inklusioner og eksklusioner selve kampen medfører. Oplevelser af mennesker, kroppe og seksualitet er ikke bare et spørgsmål om rigtigt eller for- 
kert, men tværtimod performative tilblivelses-processer, som finder sine betydninger i selve tilblivelsen. I temaredaktionens optik tilbyder disse radikale og provokerende billeder en spændende visuel fortolkning af, hvad queer (også) kan være og udgør således, i linje med artiklerne, et vigtigt bidrag til den diagnose over queer i dag, som vi håber, at temanummeret kan medvirke til at stille.

\section{QUEER SOM MULIGHED}

Mod denne eller disse baggrunde vil vi med dette nummer af Kvinder, Køn \& Forskning prøve at gribe de muligheder, der byder sig ud fra queers radikale fortid, såvel som dets ambivalente nutid, for at illustrere queer teoriers fortsatte - ja, akutte - relevans som kritisk perspektiv på det neoliberale og heteronormative samfund (Butler 2009; Halberstam 2008; Weiner and Young 2011). Det er netop dets elegante samspil med og kritiske blik på tidens ånd, kombineret med de muligheder queer giver os for at afsøge senmoderne fænomeners normerende funktion(er) såvel i internationale politiske regimer som i lokale og hverdagsnære praktikker, der har lokket os til at mobilisere queer igen - nu mere end tyve år efter at begrebet først blev brugt i kampen mod 'the charmed circle' af heteroseksuel lyst og begær (Rubin 1999). Og med vores forkærlighed for queer $\mathrm{i}$ alle sine former er vi temaredaktører selvfølgelig også børn af tidens ånd. Vi har læst Butler og Foucault som selvfølgelige dele af vores poststrukturalistiske pensum på vores universitære grunduddannelser efter årtusindskiftet, og vi er dermed en del af den generation, der er vokset op med at (kunne) tænke køn og seksualitet som individets potentielle legeplads, men samtidig smerteligt bevidste om normernes veldefinerede og -bevogtede grænser. Og modsat Henning Bech, som i Skave køn fandt det nødvendigt at sxtte "queer teori” i gåseøjne og udefra forklare, hvad begrebet eventuelt kunne komme til at betyde (Bech 2003:6-17), er denne udgave et blik på og bidrag til queer teorier indefra og uden gåseøjne, men med lidenskab for en tankefigur/livsstil/akademisk position, der bliver ved med at inspirere os og andre forskere, kunstnere og aktivister til nye drømme, ideer og projekter. I Danmark kommer dette fx til udtryk gennem initiativer som QUEERKRAFT (en hjemmeside som 'kaster kritiske blikke på venstrefløjens politik og praksis ud fra queerperspektiver, -identiteter og -praksisser'), Copenbagen Queer Festival (en årlig DIY (do it yourself) festival, som har til formål at skabe åbne og queer rum) samt scener som Warehouse 9 ('et rum for nutids-moderne kunst, musik, poesi og performance med en direkte forbindelse til det internationale queer miljø'), der alle er queer interventioner i majoritetskulturens måde at tænke samfund, hverdag og politik på og vigtige kilder til kraft og visioner for alle der, som vi og Judith/Jack Halberstam, drømmer om 'a queer time and place' (Halberstam 2005).

Nogle af de mest interessante og signifikante nyere teoretiseringer i den queer sfære tager netop fat på de analyser, som Halberstam identificerer som vejen mod 'den queer tilstand': at anlægge kritiske perspektiver på de senkapitalistiske og nationalistiske diskurser, der dels muliggør en såkaldt lyserød økonomi, hvor konsumentkulturens løfte om at opfylde alle vores drømme bliver til et fællesskabende faktum, der forventes at overbygge alle andre interessekonflikter, og dels mobiliserer en såkaldt lyserød rengøring (pinkwashing), hvor øget statslig tolerance overfor og rettighedstilkendelse til bøsser og lesbiske (men sjeldent transpersoner, queeridentificerede og intersexindivider) sker simultant med og dækker over - anvendelsen af statslig vold mod andre stater, grupper og enkelte individer. Som Jasbir Puar har påpeget (2007), må lgb(tqi)-politik således altid sættes i (kritisk) relation til øvrige politikker og diskurser på et givet område. Et land 
som i høj grad forbindes med pinkwashing, er Israel. Som Jasbir Puar, Judith Butler og flere andre har påpeget, benytter Israel aktivt sin selvproklamerede gay-friendliness til at udpege palæstinensere og muslimer som mindre tolerante og legitimerer dermed indirekte sin aggressive besættelsespolitik på det palæstinensiske område. På samme måde promoverer også Danmark en statslig åbenhed og homovenlighed, som sandsynligvis ikke kan genkendes af hverken unge transpersoner, der fortsat ikke tillades at bestemme over egne kroppe og hormoner, lgbtqi-personer, der i årevis sidder indespærret på danske asylcentre eller alle de andre, der på forskellig vis distancerer sig fra det (hvide) monogame, tosomme kernefamilieideal. Også i multinationale virksomheder kan en lyserød rengøring reducere lgbtqi-kollektivets (og mange andre sociale bevægelsers) årelange kampe for synlighed og politiske rettigheder til chikke elementer i reklamekampagner. Danske Bank har eksempelvis fået meget kritik for sin reklame $A$ new normal demands new standards. Her bruges billeder af blandt andet to kyssende kvinder, Oscar Pistorius (sydafrikansk professionel løber med proteser for to amputerede underben) og en kvinde $\mathrm{i}$ jakkesæt (som symboliserer kvindernes fremskridt på arbejdsmarkedet) til at profilere banken som en innovativ, international og åben virksomhed. Dermed gøres disse, og alle andre menneskers smertefulde modstand og kamp mod den hvide heteroseksuelle mandlige norm, til små krydderier i poleringen af en virksomheds offentlige image. En virksomhed som i alle andre henseender ikke har noget som helst med disse menneskers kampe at gøre - et typisk eksempel på lyserød rengøring i kapitalismens navn.

\section{QUeER DENNE GANG}

På sin rejse fra periferi til om ikke centrum så 'anerkendt' perspektiv og referencepunkt i dansk og skandinavisk forskning har 'det queer blik' været appliceret på en lang række forskellige teoretiske, metodiske og empiriske felter, og vigtigt pionerarbejde er udført af en række forskere, hvoraf flere medvirker i nærværende tidsskrift. Artiklerne og billederne vi bringer her vidner netop om den bredde og alsidighed, der findes $\mathrm{i}$ queer analyser på det akademiske felt i Skandinavien i dag.

Michael Nebelings artikel "To Belong to the Living - om queer slægtskab og reproduktiv futurisme" indleder ballet med en kritisk læsning af Lisa Cholodenkos film The Kids Are All Right og viser, hvordan filmen - trods at den i mainstreammedier blev hyldet som en progressiv skildring af 'nye familieformer' - indskriver sig i (neo)konservative slægtskabsideologier, hvor normaliseringen af 'den lesbiske familie' vilkårliggør en abjektifiering af klassemærkede og racialiserede Andre. Nebeling foretager ved hjælp af begrebet 'reproductive futurism' (Edelman 2004) og Sara Ahmeds teoretiseringer af 'queer attachments' (Ahmed 2010 ) en reparativ analyse af filmen for at vise de omfattende indsatser, filmens hovedpersoner må udføre for at opretholde sin legitimitet som familie.

I artiklen "Krumme tæer - skam i krydsfeltet mellem queer, feministiske og postkoloniale teorier" tager Maja Mons Bissenbakker Frederiksen feministiske og queer teoriers store interesse for skamteorier under behandling og viser, hvordan ukritiske anvendelser af skambegrebet reproducerer universalistiske forestillinger om 'det fællesmenneskelige' uden at synliggøre denne konstruktions imaginære og ekskluderende karakter. Artiklen viser, hvordan postkolonial og cripteoretisk inspireret kritik af forestillinger om skam kan bidrage til at nuancere vores forståelser af, hvordan skam kan anvendes både subversivt og ekskluderende, og hvordan queer teorier - i dette tilfælde queerinspireret skamteori - kan og bør bidrage til en vedvarende selvkritik blandt ak- 
tivister, kunstnere og - ikke mindst - akademikere.

At udfordre den akademiske praksis er også Hanna Hallgrens mål. I hendes bidrag "En queer introduktion till Gränslösa bundarOm queerteori, performativitet och subversiva repetitioner i skönlitterära, kritiska och vetenskapliga texter" udfordrer hun den måde, vi skriver, læser og forstår tekster på, særlig når de benytter sig af queer ikke bare som et analytisk instrument, men også som skriftlig praksis. Hallgren tager udgangspunkt i sin og Jenny Tunedals poetiske tekst Gränslösa hundar (som kan findes på Kvinder, Køn \& Forsknings hjemmeside: http://tidsskrift.dk/index.php/KKF/issue/current) og udforsker i artiklen tekstlig queer performativitet. I en collage af stilistiske og tematiske niveauer peger hun på, hvordan queer teorier tilbyder specielle muligheder for performativitet både langs med og på tværs af grænserne for akademisk-, essayistisk- og poetisk skrivning.

I det afsluttende bidrag "Queer Theories, Critiques and Beyond" diskuterer Christel Stormhøj genealogien af queer kritik. Hun peger på queer kritik som et projekt, der har rødder $i$ et bredt felt af den vestlige filosofiske historie, men som også samtidigt er et projekt med særlige forståelser af subjekt og fællesskab. Gennem læsninger af queerteoretiske klassiskere som Butler, Warner og Sedgwick udpeger Stormhøj de begrænsninger denne historie medbringer, og viser hvordan en queer kritik på den anden side af disse begrænsninger kunne se ud.

Med disse forrygende bidrag håber vi at læserne, ligesom vi, ser den bredde og skarphed som til stadighed præger og udvikler queer teorier såvel metodologisk som stilistisk i mødet med fortid, nutidens udfordringer og dets teoretiske fremtidsperspektiver. Vi vil med temanummerets titel [kvear] pege på både den relativt ukritiske hverdagsbrug, som vi synes, at queerbegrebet har indtaget i det decennium, der er gået siden Skave køn og samtidig skrue op for den vrængende kritiske røst, som altid råber i baghovedet på alle os, der på forskellig vis lever i og med queer som akademisk og aktivistisk tilstand.

\section{Note}

1. LGBTI er en samlingsbetegnelse for lesbiske, bøsser, biseksuelle, transpersoner og intersexindivider.

\section{LITTERATUR}

- Ahmed, Sara (2010): The Promise of Happiness. Duke University Press, Durham.

- Ambjörnsson, Fanny (2006): Vad är Queer? Natur och Kultur, Stockholm

- Berg, Martin and Jan Wickman (2010): Queer.

Liber, Malmö

- Bjørby, Pål and Anka Ryall (2008): Introduction: Queer Theory in a Norwegian Context, i: Journal of Homosexuality 1-2/2008 (1-8)

- Butler, Judith (2009): Frames of War: When Is

Life Grievable? Verso, London

- Dahl, Ulrika (2011): Queer in the Nordic Region: Telling Queer (Feminist) Stories, i: Downing, Lisa \& Gillett, Robert (red.) (2011): Queer in Europe: contemporary case studies, Ashgate, Farnham

. Downing, Lisa \& Gillett, Robert (eds.) (2011): Queer in Europe: contemporary case studies. Ashgate, Farnham

- Duggan, Lisa, Hunter, Nan D. (1995): Sex Wars: sexual dissent and political culture. New York, Routledge

- Dworkin, Andrea (1989): Pornography: Men Possessing Women. Plume, New York

· Edelman, Lee (2007): No Future: Queer Theory and the Death Drive. Duke University Press, Durham, London

- Ferguson, Ann (1984): Sex War: The Debate Between Radical and Libertarian Feminists, i Signs 1984, vol. 10, no. 1 (106-112)

- Halberstam, Judith (2005): In a Queer Time and Place: Transgender Bodies, Subcultural Lives. New York University Press, New York 
- Halberstam, Judith (2008): Animating Revolt/ Revolting Animation: Penguin Love, Doll Sex and the Spectacle of the Queer Nonhuman, i: Noreen Giffney and Myra J. Hird. (eds.): Queering the Non/Human. Ashgate, Burlington

- Heede, Dag (2012): Queerteorien i Danmark eller hvordan jeg blev mærkelig, i: Kvinder, Køn \& Forskning nr. 32012 (19-24)

- Kulick, Don (1996): Queer Theory: Vad är det och vad är det bra för?, i: lambda nordica 3-

4/1996 (5-22)

. Kulick, Don (2005): Queersverige. Natur och

Kultur, Stockholm

- Puar, Jasbir (2007): Terrorist Assemblages:

Homonationalism in Queer Times. Duke Press,

New York
- Rosenberg, Tiina (2002): Queerfeministisk Agenda. Atlas, Stockholm

- Rubin, Gayle (1999): Thinking Sex: Notes for a Radical Theory of the Politics of Sexuality, i: Culture, Society and Sexuality - A Reader (143-178), Richard Parker and Peter Aggleton (eds.). UCI Press, London

- Vance, Carole S. (1984): Pleasure and Danger: exploring female sexuality. Routledge \& Kegan Paul

- Weiner, Joshua and Damon Young (2011):

Queer Bonds, i: GLQ: A Journal of Lesbian and Gay Studies 17.2-3/2011 (223-241) 